\title{
THE LAW VERSUS THE CONSCIENTIOUS OBJECTOR
}

\author{
Francis Heister $\dagger$
}

I T IS NOT TO BE PRESUMED, without proof, that the title of this article implies that the laws of the United States as they apply to the conscientious objector are against him. While, from the proof that follows, this may appear to be the case, for the present, the title to me is a juxtaposition of the law and of those who are conscientiously opposed to the use of violence and who, therefore, cannot participate in war in any form.

The Draft Law of $1917^{1}$ recognized as conscientious objectors only a few of those who were members of the historic peace churches, i.e., members of the Society of Friends, Mennonite, and Brethren Churches. Even those few who, during the first World War, were given exemption from military service as conscientious objectors, had to pay dearly for the congressional "grant" and were given treatment often worse than that meted out to criminals. ${ }^{2}$

The Draft Act of $1940^{3}$ substantially embodied the wording of the Act of 1917 , with the departure that "religious training and belief," instead of membership in the historic peace churches, was made the basis on which conscientious objection to war could be claimed. The exception covering conscientious objectors is given by Section $305(\mathrm{~g})$ :

Nothing contained in this Act shall be construed to require any person to be subject to combatant training and service in the land or naval forces of the United States who, by reason of religious training and belief, is conscientiously opposed to participation in war in any form. Any such person claiming such exemption from combatant training and service because of such conscientious objections whose claim is sustained by the local board shall, if he is inducted into the land or naval forces under this Act, be assigned to noncombantant service as defined by the President, or shall, if he is found to be conscientiously opposed to participation in such noncombatant service, in lieu of such induction, be assigned to work of national importance under civilian direction.

We are told that the formulation of Section $305(\mathrm{~g})$ was given to the military authorities for recommendation to Congress by two churchmen who unquestionably believed that the intent would be carried out in accordance with the "fair and just system of selective compulsory military training and service" stated as the objective of the Act in Section 301(b). However, British experience with local board determinations in the first World War, in consequence of which the

$\dagger$ Member of the Illinois and California Bars.

140 Stat. 76 (1917), 50 U.S.C. App. $\$ \$ 201-11$ (1940).

2 Thomas, Is Conscience a Crime? (1927); Gray, Character, Bad (1934); Pacifist Handbook (F.O.R., 1939); Allen, The Fight for Peace (1930).

354 Stat. 885 (1940), 50 U.S.C. App. $\$ \$ 301-18$ (1940). 
later British law provided a separate register and a special tribunal to pass upon the claims of conscientious objectors, should have provided a warning. ${ }^{4}$

The British did not expect, and we should not have expected, that local boards confronted with the urgent task of filling the assigned draft quotas would pay - with laudable exceptions-more than perfunctory attention to the claim of the conscience. It was not to be expected that draft board members, untrained in administering the law, would go to the trouble or even have the time to examine and understand the problems involved in the reason of "religious training and belief."

\section{Due Process Before Local Draft Boards}

Experience since the adoption of the Draft Act of 1940 has shown that the local boards neither were qualified nor did they endeavor, in most instances, to apply a "fair and just"system to the conscientious objectors, but rather attempted to fill their quotas by denying objector classifications wherever there was the slightest justification for doing so. A few recent case histories" of "conchees," as they soon came to be called, will illustrate this failure of the system.

A young man near Hammond, Indiana, claimed exemption from both combatant and noncombatant service. His claim was recognized by his board as having been based upon "religious training and belief." However, he was not classified 4-E (exemption by Congress from both combatant and noncombatant service), but rather 1-A-O (exemption from combatant service only). He was ordered, on September 5, 1942, into an army camp where he refused training, still claiming conscientious objection to war in any form. He was thereupon court martialed and sentenced to two years in the guardhouse. Two hundred and one days later, the Inspector General inquired into his case and brought about the conscientious objector's discharge (a blue one, meaning neither honorable nor dishonorable discharge). The discharge papers carried the remark of the military authorities that he "is not recommended for reenlistment." This should have brought about a reclassification by his draft board as 4-F (not acceptable for military duty for physical, mental, or moral reasons, or just "for the good of the service"). But the draft board then became convinced that the man should be given a $4-\mathrm{E}$ classification, which they failed to give him in the first instance, instead of the legally required 4-F. On February 8, 1944, he was inducted into a Civilian Public Service Camp. While there, he contacted counsel for the purpose of obtaining his freedom from illegal confinement by writ of habeas corpus. ${ }^{6}$ The approach of the district attorneys was, in most cases, better than that of the draft boards, and a discussion of the filing of the writ brought about release of the young man.

Another registrant was a licensed Methodist minister with a church in Lin-

'British Nat'l Service (Armed Forces) Act of 1939, reported in 1 Krusin and Rogers, The Solicitors' Handbook of War Legislation 388 (1940).

${ }^{5}$ All unreported cases discussed in this article are from the author's files.

- Morris A. Bell v. Camp Administration, W.D. Mich., N. Div., (1944) (not reported). 
coln, Nebraska, and under the law, he was given a classification of 4-D (ministers of a recognized church). Subsequently, he gave up his pastorate to become Western Secretary of the Fellowship of Reconciliation, a Christian lay organization devoted to pacifism. He so informed his draft board, indicating that he was a minister; nevertheless, the draft board promptly changed his classification to that of $4 \mathrm{E}$ and ordered him to take a physical examination prior to induction into a Civilian Public Service Camp. This order was sent to him when he was already enrolled in the Chicago Theological Seminary. The President of the Seminary wrote to the draft board pleading with them to reconsider and reinstate the proper $4-D$ classification. The board refused and turned over the files to the Department of Justice for prosecution. The minister was indicted and was tried in May, $1944 . .^{7}$ Counsel attempted to present evidence as to the illegal conduct of the draft board. The judge, however, misconceiving the decision in Falbo v. United States, ${ }^{8}$ about which I will speak later, refused to consider any of the evidence offered and, simply on the basis of defendant's refusal to be inducted, sentenced the minister to three years in the federal penitentiary. The judge was surprisingly mild. He did not scold Axford but said "You are evidently a young and foolish man. You want to be a martyr and I am going to sentence you to prison for three years." A little later he said "You have nothing to fear. Jesus Christ was crucified and came back again." Roger replied "Yes sir, under Pontius Pilate." It was a dramatic moment and one wondered what the Judge was thinking. ${ }^{9}$

Local boards, as the following case illustrates, will maintain their position as to the classification even though everyone, including the Department of Justice and Selective Service headquarters, disagrees with them. A young man was studying for the priesthood at St. John's University in Minnesota. He was, under all the interpretations of the law, entitled to a deferment under the appropriate classification of $4 \mathrm{D}$. For reasons best known to the local board, he was classified 4-E, i.e., a conscientious objector who, as such, was to go to a Civilian Public Service Camp and, consequently, to abandon his studies as a divinity student. Everyone involved, including the trial judge before whom the case was pending, ${ }^{10}$ suggested that, in the interest of "fair and just" application of the law, the file ought to be opened and the subject given 4-D classification. National headquarters of Selective Service investigated the seminary at which the defendant was studying and informed the State Director of Selective Service of Minnesota that St. John's met the qualifications of a divinity school under the Act and that the defendant had been duly admitted as a student there.

All of this was of no avail, because the draft board obtained from somewhere the erroneous information that 4-D classification was allowable only to those who had finished four years of studies as divinity students. Since the student in

7 United States v. Roger Axford, N.D. Ill., E. Div., 44 Cr. 147 (1944) (not reported).

8320 U.S. 549 (1944).

'Palmer, The Axford Case, The Open Door (Chicago Theol. Seminary, May 20, 1944).

${ }^{10}$ United States v. Robert Walker Havda, N.D. Ill., E. Div., 43 Cr. 449 (1943) (not reported). 
question had not finished his studies, he was refused the classification to which he was entitled. His refusal to be inducted was followed by an indictment. Fortunately, the trial judge saw fit to grant a suspended sentence, which, in the early stage of the war, was an unheard-of procedure. The defendant was permitted to return to divinity school to complete his studies, but not before he was found guilty of a felony-the violation of the Selective Service Act-which carries a possible sentence up to five years in the penitentiary and/or a $\$ 10,000$ fine.

While, in the preceding case, "due process"11 prevented the board from reopening the files for reclassification, that is not always the case. Contigencies may arise even during the trial which will cause a reopening. So it happened when a defendant received a 1-A-O classification when he asked for full exemption as a 4-E. He refused induction and was indicted and tried. ${ }^{12}$ The draft board clerk testified that the defendant, in filling out his questionnaire for conscientious objectors, marked the square which indicated that he objected only to combatant service. The defendant claimed that he placed his mark in the square that indicated his objection to military service entirely. The questionnaire in evidence seemed to bear out the testimony of the draft board clerk. While defense counsel was examining the document, a shaft of sunlight hit it, disclosing a yellow spot that could have resulted from the use of ink eradicator. Defendant denied the erasure and while it was not determined who was guilty of the forgery, the draft board gladly accepted the proposal that the prosecution be terminated and the defendant be classified as 4-E. He subsequently received his assignment to a Civilian Public Service Camp.

Ignorance of draft board members regarding the Selective Service Act frequently results in injustices. Such was the case when a registrant, whose claim as a conscientious objector was recognized by the board, asked for a $4 \mathrm{E}$ classification, yet was granted the lower exemption, ${ }^{13} 1-\mathrm{A}-\mathrm{O}$, on the ground that a conscientious objector must first be classified as $1-\mathrm{A}-\mathrm{O}$ and be inducted into the army before he could get his $4-\mathrm{E}$ classification. While ignorance of the law by draft board members results more often than not in injustices, sometimes the ignorance redounds to the benefit of the registrant if he has the opportunity to present his case to an understanding judge during the subsequent trial. A registrant's draft board refused a request for a 1-A-O classification on the sole ground that the draft board did not know that there was such a classification. Since he did not ask for 4-E classification, but instead the exemption from combatant

${ }^{11}$ Objections directed to lack of due process embrace both procedural and substantive aspects. In the early trials, the defendants insisted that substantive due process, and parallel therewith the First Amendment, be invoked, since they, as religious objectors, believed that raising of procedural due process questions would not be in line with their "religious training and belief." Subsequently, the lack of procedural due process was invoked and, more often than not, with greater success than lack of substantive due process.

12 United States v. Jack Mendro, N.D. Ill., E. Div., Criminal No. 33,419 (1942) (not reported).

12 United States v. Barnett, N.D. Ill., E. Div. (1944) (not reported). 
service only, he was classified as 1-A and ordered to report for induction. The registrant refused to report and was indicted. ${ }^{14}$ Because of the ignorance on the part of the entire board (including the chief clerk, who is supposed to be completely informed about the rules and regulations), the judge dismissed the case and had the files transferred to the board for proper reclassification.

If the quality of the boards had been on a somewhat higher level, much of this sort of injustice could have been avoided. Can it, however, be expected that the qualifications of the draft boards can be adequate other than by accident, considering the appointment of the thousands of board members to operate the many thousands of local boards? Board members are appointed by the governors of the states who, of course, make their appointments on the recommendation of their local patronage dispensers. The members are not paid, and one wonders that, under the circumstances, they give even as much consideration as they do to the claims of conscientious objectors. In any case, the system has resulted in untold hardships and in the incarceration of many thousands of young men whose only crimes were that the board members lacked both time and qualification to determine "fairly and justly" the question of conscience.

The system also brought about the appointment of board members who carried with them into their administrative functions all the prejudices of the locality. This becomes abundantly clear from the case of a Nisei registrant who had asked to be classified 4-E as a religious objector to the war. Because of his physical condition, he was classified 4-F in 1940 . Subsequently, he was removed from the west coast, together with others of Japanese descent, and placed in a relocation camp at Merced, California. In 1943, he was reclassified as 4-C (this class includes an enemy alien and one "who because he is an alien or because of his ancestry [is] unacceptable for training and service").

On February 29, 1944, having heard that all "prisoners" in the relocation camp were reclassified 1-A, he wrote his draft board asking that he be sent the necessary forms to prove his claim as a conscientious objector. The board answered, in substance, that the registrant should stop bothering them, because, as they wrote, they wanted to have nothing to do with his kind of people. The registrant was reclassified as 1-A in March, 1944. This classification was obviously incorrect, because if he were an enemy alien, although born in this country, then he could not be drafted unless he waived his exemption as an alien. If he were classified as $4-\mathrm{C}$, indicating he was not acceptable to the military, there was no showing that the military had changed its mind and now considered him acceptable. On May 13, 1944, he was ordered to report for a pre-induction physical, and when he would not comply with the order because of his conscientious objection to war, he was indicted. ${ }^{15}$

The local board transferred his file to Chicago, where the government appeal

14 United States v. Marvin Engert, N.D. Ill., E. Div., 43 Cr. 606 (1943) (not reported).

${ }^{15}$ United States v. George Nakagawa, N.D. Calif., E. Div. Sacramento (1945) (not reported). 
agent, having looked over the files, wrote to General Hershey asking that Hershey appeal from the determination of the local board or that he request the board to reconsider the classification of the registrant.

Registrant's Chicago counsel wrote to both the State and the National Director of Selective Service urging reopening of the files, but to no more avail than the Chicago appeal agent. The trial took place, and because of another instance of the court's misinterpretation of the Falbo decision, the registrant was refused a hearing on any evidence but proof of his refusal to be inducted, and was sentenced to two years in the penitentiary.

His local board reclassified him following his release from prison, not as $4 \mathrm{~F}$ as he should have been classified, but as $4-\mathrm{C}$, indicating that the registrant was an enemy alien or an alien not acceptable to military service. In short, the draft board first wrongly classified him 4-C, then wrongly classified him 1-A so that he would be sent to the penitentiary for refusal to be inducted, and then again 4-C.

There are many more cases in the files pertaining to conscientious objector cases during the war. Many, if not most of them, would indicate that because of the unfortunate system that gives draft boards the duty of passing on the claims of conscientious objectors, due process is denied them.

One might expect that the short shrift given to due process by draft boards was limited to the war period, a period when nerves were frayed, when emotional tension was at a peak, and when resentment against "conchees" who escaped war service by assignment to road gangs could be understood. However, the record of peace-time draft boards does not indicate any improvement. Members of the Fundamentalist Christian Church, known as the Harshmanites of Sullivan, Illinois, are given today less consideration when they claim conscientious objection to war than they were given during World War II. Some youthful members of the Church of Jesus Christ were given exemption from war service during the war, being classified as $4 \mathrm{E}$, but when caught in the peacetime draft were refused equivalent classification. The draft board considered it sufficient compliance with the law when they were granted exemption from combatant service only. These religious pacifists were unable to accept any kind of military service, and at least two of them were indicted..$^{16}$ Five other young church members are awaiting indictment at the present writing.

\section{Due Process Before the Appeal Board}

The Rules and Regulations of the Act provide for appeals from draft board decisions. The Rules permit the aggrieved registrant to have his files sent from the local board to the appeal board, but his written complaint cannot be supported by personal appearance. The procedure does include, however, the appearance before a hearing officer appointed by the Department of Justice as a Special Attorney General. The hearing officer has the benefit of an investigative

16 United States v. William Wyeth Duncan, N.D. Ill., E. Div., 52 Cr. 498 (1952) (not reported); United States v. Richard Rodney Harris, N.D. IIl., E. Div., 52 Cr. 497 (1952) (not reported). 
report obtained by agents of the FBI which is not available to the registrant. In fact, the report is not available to the appeal board, although in many cases, the report of the hearing officer will make reference to certain "informants" " statements. Having no access to the investigative report, not knowing who the informants were nor what their statements were, and being unable to confront them and thus to combat them, conscientious objectors clearly seem to be denied procedural due process.

It is probably not inaccurate to assume that the FBI agents will try to locate informants whose statements will support the draft board's decision. Therefore it is to be expected that, as a rule, the draft board's decision will be upheld by the appeal board. In fact, it may happen that the investigative report will bring before the appeal board additional information prejudicial to the conscientious objector, and while, under the Rules, the appeal board cannot lower the registrant's classification, attempts have been made to do so in at least one instance in our files. ${ }^{17}$ This necessarily resulted in a not guilty verdict in a subsequent indictment and trial for refusal to report for induction.

Not only is the registrant prevented from confronting "informants" against him, but he may not have counsel when appearing before the hearing officer (as he could not have legal advice before the draft board). In consequence, young registrants have to fend for themselves when confronted with the maze of complicated regulations that even the administrative agencies are unable to cope with properly.

In addition to issues involving the First Amendment, ${ }^{18}$ the question of lack of due process before the appeal boards is the point most often raised by conscientious objectors at their trials. Until recently, the courts have refused to pay much attention to those claims. However, in at least three instances, district courts have, within the last few months, decided that the withholding by the FBI of the investigative report both from the registrant and from the appeal board represents such denial of due process that the order of induction becomes void and requires a finding of "not guilty."19

The effect of such proceedings may be fully understood if one considers the case in which the content of the secret investigative report became known to the registrant because the fragmentary information permitted only one conclusion, namely that the report was false. The registrant was a member of the Mennonite Church and asked for conscientious objector classification as a member of an

17 United States v. Herbert William Hutchins, E.D. Mich., N. Div., Criminal No. 4,402C (1947) (not reported).

18 Constitutional issues that were raised by counsel for defendants were based, in the main, on the First Amendment, which forbids Congress to enact any law restrictive of religious freedom or of the free exercise of religion. The contention of the defendants was that the Selective Service Act, if in conflict with their religious practice as prescribed by their church rituals, must be resolved in favor of religious freedom, as dictated by the Constitution.

19 United States v. Joseph Oller, Jr., D. Conn., Criminal No. 8,606 (1952) (not reported); United States v. Raymond T. Donovan, D. Conn., Criminal No. 8,621 (1952) (not reported); United States v. Andrew Geyer, D. Conn., Criminal No. 8,654 (1952) (not reported). (Author did not represent these three defendants.) 
historic peace church, so recognized for hundreds of years in this country. $\mathrm{He}$ was given a 4-E classification. The registrant at that time was employed in a factory that produced, in addition to its usual civilian goods, machinery that was adaptable for war purposes. The factory had a defense plant classification and, in consequence, the registrant was given a classification as a defense worker. Therefore, registrant's classification was changed from 4-E and he was classified as a defense worker, 2-B.

Subsequently, while still working in the defense plant, the registrant was again reclassified 4-E and his employer requested that he again be given occupational deferment. However, his local board reclassified him as 1-A, utterly disregarding his previous claim, twice recognized, for classification as a conscientious objector. Thereupon the registrant carried his case to the appeal board. However, his appeal was not granted and his classification of 1-A was reaffirmed.

During the hearing before the appeal agent, the registrant was given some fragmentary information that his conscientious objector status was denied to him because, according to certain informants, among them a Mennonite bishop and a Mennonite minister, the registrant was not a member in good standing in the Mennonite Church because he accepted employment in a defense plant. There was only one Mennonite bishop and one Mennonite minister in the territory, so it was not difficult for defense counsel to contact them. They promptly denied not only giving the information, which they claimed to be false, but also that they were ever interviewed by the FBI agent as the hearing officer's report claimed. At this point, the case became almost an impasse because the FBI agent who allegedly obtained interviews from the bishop and minister would not recant, even though upon confrontation both the bishop and the minister denied ever having met the FBI agent.

It was a difficult decision for any judge to make-whether to consider the FBI agent or the high dignitaries of the Mennonite Church prevaricators. To avoid embarrassment, the government, for the first time in the experience of the author, agreed not to object to a suspended sentence, provided that the question of "who is telling the truth?" would not be pressed. Since the registrant was satisfied to plead "not guilty" and to be given a suspended sentence in case he was found guilty-as he was-the matter was dropped, more particularly because it became obvious during the many pretrial conferences that the hearing officers, at least in the district in question, would be much more careful thereafter in using the secret investigative report. ${ }^{20}$

\section{Due Process on Further Administrative Appeal}

Under the Rules and Regulations of the Selective Service Board, the State Director of Selective Service, as well as the National Director, has the authority to appeal from the decision of the appeal board to the Presidential Appeal Board. It may be fairly assumed that the State Director, whose job is to fill the state quota, seldom, if ever, will feel moved to bring about the reversal of the

${ }^{20}$ United States v. Nolan Book, N.D. Ill., E. Div., 45 Cr. 310 (1945) (not reported). 
decision of his state appeal board. The National Director, while confronted with the same consideration, has demonstrated, in general, a greater concern toward fair proceedings and presidential appeals have been taken by him.

The Act provides, ${ }^{21}$ so far as we can understand the law, that the matter of conscientious objectors is the concern of civilians. The President, by executive order, made the Director of Selective Service (most of the time during the period involved, it was a general of the United States Army) the executive head of the Presidential Appeal Board, and this executive appointed the members of the Appeal Board almost exclusively from the ranks of military men. The fact that presidential appeals of conscientious objectors are not often effective may be ascribed to the fact that military men pass upon this final administrative appeal. In fact, the National Director of Selective Service himself passes upon the question of whether or not such presidential appeal should be taken at all. It is much more a whim than the execution of the law, either of the letter or of the spirit, that prompts the processing of such appeals, as is well demonstrated by the case of United States v. George Nakagawa, discussed later. ${ }^{22}$

\section{Due Process in Crvituan Public Service Camps}

Those conscientious objectors who were able to convince their local board in the first instances; or, in failing to do so, their appeal board; or, in case of a further failure, the Presidential Appeal Board, that they were entitled to a conscientious objector's classification - and if found physically fit to do "work of national importance."-were sent to Civilian Public Service Camps in various parts of the country. The law provides that

[a]ny such person claiming such exemption ... shall, if he is found to be conscientiously opposed to participation in such noncombatant service, in lieu of such induction be assigned to work of national importance under civilian direction.23

Before the enactment of the Act and the Regulations of Selective Service, the representatives of the historic peace churches and other civilians undertook the financing of these camps, with the intention of avoiding any opportunity for conflict on the part of those conscientious objectors who might be unwilling to go to Civilian Public Service Camps if such camps were under military control.

The National Director of Selective Service, however, placed the work projects under his, a general's, direction. How he was able to reconcile the meaning of the words "civilian" and "general" is difficult to determine. The Regulation says: The Director of Selective Service is authorized to establish, designate, or determine work of national importance under civilian direction. ${ }^{24}$

But General Hershey placed the camp operation division under the direction of Lewis F. Kosch, who customarily signed all directives as "Col. (in the beginning, Lt. Col.) Field Artillery, Chief Camp Operation Division." Selective Service

254 Stat. 885 (1940), 50 U.S.C. App. $\$ 301$ et seq. (1940).

${ }^{2}$ N.D. Calif., E. Div. Sacramento (1945) (not reported).

${ }^{23} 54$ Stat. 885 (1940), 50 U.S.C. App. 305(g) (1940). (Emphasis added.)

${ }^{24}$ Selective Service Reg. 653.1(a) (1944). (Emphasis added.) 
Headquarters and, particularly, the camp operation for conscientious objectors was staffed with military men, according to Colonel Kosch's own testimony. ${ }^{25}$ Conscientious objectors, in many instances, walked out of the camps because they believed that, in accordance with the dictates of their consciences, they could not serve under army officers.

Selective Service repeatedly denied that the assignment of conscientious objectors to Civilian Public Service Camps was in any way punitive. But, although soldiers, and particularly the families whom they left behind, were provided with the minimum necessities in the form of family allotments, the Regulations provide that:

The Director of Selective Service is authorized to pay assignees in Governmentoperated camps. The pay of assignees shall not be more than $\$ 5.00$ per month except that not to exceed 6 percent of the assignees may be paid not more than $\$ 7.50$ per month. ${ }^{26}$

No uniforms were assigned to conscientious objectors. ${ }^{27}$ Thus, out of the $\$ 5.00-$ or maximum $\$ 7.50$-assignees in camps as long as five years were to provide their clothing, shoes and other such items, which, in many cases, required substantial replacement. No provision whatsoever was made for the families of assignees. No life insurance or accident insurance was provided, although a physician, or at least a perambulating one, was assigned to each camp.

The conscientious objectors were assigned at the camp to their work. However,

[n]o limitation [was] set on the number of hours that an assignee may be required to work in any given day or week. Forty-four hours per week shall be the minimum that any assignee shall work. Travel time shall not be included in computing the 44-hour minimum, except the portion thereof which exceeds 1 hour in any one day..$^{28}$

During the shortage of agricultural labor, conscientious objectors in camps were detached by an order providing the assignment of conscientious objectors to farmers. ${ }^{29}$ However, the conscientious objectors were not to receive the prevailing wages, because wages due were paid through the Projects Superintendent to the United States Treasury. Even those assigned to agricultural projects were not paid; they were told that the work was not voluntary and that men refusing to perform the farm labor were subject to prosecution.

It may be that the Director of Selective Service believed it when he said that assignment to Public Service Camps was not a punitive measure, but conscien-

\footnotetext{
${ }^{25}$ Report of Hearing before a Sub-Committee of the Committee on Appropriations, House of Representatives, 78th Cong. 1st Sess. (1943).

${ }^{20}$ Selective Service Reg. 653.3(e) (1944).

${ }^{27}$ Selective Service Reg. 691.12 (1944).

${ }^{28}$ Selective Service Reg. 691.22 (1944).

${ }^{29}$ Selective Service Order (July 30, 1943).
} 
tious objectors, reading the statement of Selective Service headquarters, ${ }^{30}$ concluded otherwise. The statement, signed by a lieutenant colonel, said:

The contention of some individuals [meaning conscientious objectors] that they are being forced to accept charity or that their service amounts to involuntary servitude is incorrect. No one is forced to accept a 4-E classification ... neither is anyone compelled to remain classified as 4-E. A 4-E can and will be classified as 1-A or 1-A-0 on request. Having accepted 4-E classification, he must take the conditions that go with it. Every man receives pay consisting of his food, clothing, shelter and a certain cash allowance. [The Lt. Col. meant the $\$ 5.00$ a month and the $\$ 7.50$ per month given to some conscientious objectors, not exceeding six per cent of all in that class.]

The reason given by the lieutenant colonel for the discriminatory treatment of conscientious objectors is formulated thus:

Since men classified as $4 \mathrm{E}$ and assigned to Civilian Public Service Camps are not called upon to assume the responsibilities or risk of the men in the service, it is to be expected that they were not extended the privileges and benefits. This applies to pay, the benefit of the Selective Service Relief Act, the National Life Insurance Act, and the Service Men's Dependents Allowances Act, all of which are extended only to the men in the armed service. It has also been ruled that service in a Civilian Public Service Camp does not entitle one to veterans preference or to re-employment rights. Neither are assignees eligible for civilian employment compensation at the present time.

If any conscientious objector had any doubt as to whether he was or was not under civilian control while in a Civilian Public Service Camp, the lieutenant colonel enlightened him by stating:

From the time an assignee reports to camp until he is finally released, he is under the control of the Director of Selective Service. He ceased to be free agent and is accountable for all of his time in camp and out twenty-four hours a day. His movemovements, acts and conduct are subject to control and regulations. He ceases to have certain rights and is granted privileges instead. These privileges can be restricted or withdrawn without his approval or consent as punishment during emergencies or as a matter of policy. He may be told when and how to work, what to wear and where to sleep. He can be required to submit to medical examinations and treatment and to practice rules of health and sanitation. He may be moved from place to place and from job to job even to foreign countries, for the convenience of the Government, regardless of his personal feelings and desires.

The spirit of the above regulation was fully carried out by the Selective Service and resulted in a great many walkouts by conscientious objectors from the camps, in turn resulting in prosecution and conviction for terms of between three and five years in the penitentiary.

Colonel Kosch, in explaining the policy of the camps and his job before the Committee on Military Affairs, testified that:

\footnotetext{
20 Statement of Selective Service Headquarters for Communication to Each Assignee in a Government-Operated Civilian Public Service Camp (1943).
} 
My job is the administering of the camps under the Selective Service to which men classified as 4-E are sent for work of national importance. Our object in sponsoring this bill is to protect the Government in future cases of claims that might come up. In other words, although these men [conscientious objectors] are not paid by the Government and thus cannot come under the Compensation Act as now written, they are forced to go to these camps and forced to work. If they refuse they are prosecuted and sentenced to a correctional institution. So if any man becomes injured under the present act there is no way for him to be compensated. ${ }^{31}$

Pursuant to congressional authorization, the President of the United States clearly designated that conscientious objectors, in lieu of induction, be assigned to work of national importance. But camps staffed with artists, students of theology, and others provided such work as removing stones from the fields and piling them up in mounds..$^{32}$ English teachers, chemistry teachers, and chemists were designated to feed wild ducks in a camp in Michigan. ${ }^{33}$ Many conscientious objectors walked out in protest against the futile and meaningless tasks assigned them and, as a result, received long-term penitentiary sentences. ${ }^{34}$

Not only were the conscientious objectors treated in this harsh spirit, but they were discriminated against at the time of the demobilization of the Armed Forces. The law provides for the confinement of conscientious objectors to Civilian Public Service Camps "in lieu of induction," and it was expected by the conscientious objectors that their term of confinement in camps would terminate as the enlisted men were discharged. This was not the case. In the Glendora camp a group of conscientious objectors, some of them in camp for as long as five years, ${ }^{35}$ became restless because of the delayed discharge. When three of them were punished for an infraction of the rules, a strike occurred and fifty-eight of them refused to perform their work. They were indicted and tried. During the process of the trial, the United States district attorney agreed to drop prosecution against thirty-seven of them. The remaining twenty-one were tried and were all found guilty.

\section{Due Process as Practiced by Some Prosecuting Attorneys CARRYing ForWard the SPIRIT OF SElectrve SeRvice Regulations}

Great latitude is given to the United States District Attorneys in the prosecution of the cases forwarded to them either by local draft boards in case the registrant refuses induction, or by the Selective Service in case of violation of the rules pertaining to Civilian Public Service Camps. The latitude observed was

s1 Report of Hearing before a Sub-Committee of the Committee on Military Affairs, Senate, Relative to Sen. 2,708, 77th Cong. 2d Sess. (1942).

22 United States v. Glaser, et al., W.D. N.Y., Criminal Nos. 4,439C through 4,444C (1947) (not reported).

s8 Bode v. United States, 151 F. 2d 535 (C.A. 6th, 1945), cert. denied, 326 U.S. 779 (1945).

34 Atherton v. United States, 176 F. 2d 835 (C.A. 9th, 1949), cert. denied, 338 U.S. 938 (1950).

${ }^{25}$ Ibid. 
particularly great when violation of the camp regulations was involved. Some district attorneys considered the violations so petty and the possible punishment so out of line that they refused to prosecute. Others believed that the slightest infraction demanded ruthless prosecution. The latter position was taken by the district attorney assigned to prosecute the so-called Minersville cases. This camp, stuck away in the Sierras, was under strict discipline and was known in other camps as a place to which recalcitrant conscientious objectors were sent. The conscientious objectors were confined to a large dormitory and, in order to obtain some sort of privacy, they hung surplus blankets from the rafters, thus forming an enclosure around the individual bunks. In May 1945, Colonel Kosch instructed the director of the camp in writing not to permit partitions in the barracks. It was not until mid-October, some five months later, that the director posted a bulletin on the camp boards directing assignees to return the excess blankets to the warehouse. Then, in January 1946, the director went to the dormitories and gave the assignees between five and ten minutes to return the blankets forming the partitions. When the alloted few minutes expired without full compliance with the order, the director reported to the district attorney's office a violation by the assignees of Selective Service regulations. ${ }^{36}$

The charges were frivolous, at least considering that the possible punishment could have been five years in the penitentiary and $a \$ 10,000$ fine. The suggestion to discontinue prosecution was brought up repeatedly by the Department of Justice, but was refused by the district attorney. Newspaper publicity attached to the case finally convinced the district attorney that criminal prosecution in the case was not warranted and the case was dropped.

At times the Selective Service Board has been successful in convincing a district attorney to carry on prosecution of the same conscientious objector more than once. One objector, whose older brother was serving a sentence because of refusal of induction, himself refused induction when he was denied a classification as conscientious objector. During the trial, the judge concluded that sending two boys from the same family to the penitentiary just because they objected to war on religious grounds, being members of a Fundamentalist church, would not best service justice. In granting a suspended sentence, the judge said, "I shall make the period of probation long enough so that he may not be again prosecuted during the war." ${ }^{\prime 37}$ But before the term of probation expired, the district attorney filed a petition to terminate probation. Defense counsel objected to the granting of the petition on the ground that the purpose was to bring a second indictment against the registrant. The court apparently did not believe that such a thing could happen. However, defense counsel was correct in anticipating it, because the registrant was indicted the second time. ${ }^{38} \mathrm{He}$ was tried and,

${ }^{36}$ United States v. Norman Charles Lawson, N.D. Calif., N. Div., Criminal No. 9,595 (1946) (not reported).

${ }^{37}$ United States v. Paul Calvin Carr, N.D. Ill., E. Div., 43 Cr. 402 (1943), 45 Cr. 542 (1945) (not reported).

${ }^{88}$ Ibid. 
although a motion to quash the indictment on the grounds of bias and prejudice of the draft board was presented, the second trial resulted in a conviction of the defendant.

The great latitude given to district attorneys is particularly apparent when the exercise of their discretion to decide whether or not the so-called nonregistrant is to be prosecuted is apparently based on whim and not on facts. Nothing but a whim may be assigned to the fact that of four nonregistrants who were indicted simultaneously, two were prosecuted, while in the case of the other two all proceedings were dropped. Their religious convictions were unquestioned, their background similar. However, of the two who were prosecuted, one had, in addition, spoken at a pacifist meeting against the prosecution of religious objectors. The other was prosecuted, as the district attorney said, because he first studied to become a minister and later abandoned those studies to follow his first love, the teaching of mathematics. ${ }^{39}$

\section{DUE Process Before the CoUrts}

It was rather bewildering, to say the least, both for the conscientious objector charged with some violation of the Selective Service Act and for the defense counsel, when they are first confronted with the ruling of the district courts that no defense may be presented, and that the only question to be decided is whether or not the defendant (a) received an order of induction and (b) refused compliance with the order. The district courts, with an almost incredible unanimity, have proceeded along those lines because of a misconception of the Supreme Court's decision in the Falbo case. ${ }^{40}$

Falbo was convicted of wilfully failing to obey an order of the local draft board to report for assignment to work of national importance. The conviction was affirmed by the Circuit Court of Appeals, ${ }^{41}$ and the defendant brought certiorari.

Justice Black, in delivering the opinion of the Court, stated:

In this process [carrying out the provisions of the Selective Service Act and Regulations thereunder] the local board is charged in the first instance with the duty to make the classification of registrants which Congress in its complete discretion saw fit to authorize. Even if there were, as the petitioner argues, a constitutional requirement that judicial review must be available to test the validity of the decision of the local board, it is certain that Congress was not required to provide for judicial intervention before final acceptance of an individual for national service. The narrow question therefore presented by this case is whether Congress has authorized judicial review of the propriety of a board's classification in a criminal prosecution for wilful violation of an

${ }^{39}$ United States v. Gregory Votaw, N.D. Ill., E. Div., 48 Cr. 565 (1948), case dismissed, Aug. 5, 1949 (not reported); United States v. Craig Wilder, N.D. Ill., E. Div., 49 Cr. 96 (1949), case dismissed, Aug.4, 1949 (not reported); United States v. Somers, N.D. Ill., E. Div., $48 \mathrm{Cr} .600$ (1948), nonregistrant convicted (not reported); United States v. Robert B each, N.D. Ill., E. Div., 48 Cr. 564 (1948), nonregistrant convicted (not reported).

40 Falbo v. United States, 320 U.S. 549 (1944).

41 Falbo v. United States, 135 F. 2d 464 (C.A. 3d, 1943). 
order directing a registrant to report for the last step in the selective process. We think it has not.... The circumstances under which the Act was adopted lend no support to a view which would allow litigions interruption of the process of selection which Congress created. ${ }^{42}$

Various counsel for defense in selective service cases argued from January, 1944 (date of decision of the Falbo case), until February, 1946,43 that the Falbo case does not preclude "judicial review of the propriety of a board's classification in the criminal prosecution for wilful violation of an order" and that it only precludes such judicial review until after "the last step in selective process" has been taken. Defense counsel also argued unsuccessfully for two years that the trial courts ought to review the board's determination when bias, prejudice, an act on the part of the board without jurisdiction, lack of due process, or other defects were present, provided the selectee went all the way in the selective process, that is, that he reported for induction, but failed to take the last step that would carry him into the Armed Forces. Unfortunately, the trial courts stopped in mid-sentence in Justice Black's statement. Therefore, they wrongly concluded that judicial review is not in place in a criminal prosecution and no defense was to be heard after the government proved the sending of an order of induction and disobedience thereto. It is unfortunate that the Supreme Court did not clarify the Falbo case, apparently assuming that the opinion spoke for itself.

The first clarification was given in the case of Estep v. United States, ${ }^{44}$ about two years following the Falbo decision. Justice Douglas said:

We found no provision for judicial review of a registrant's classification prior to the time when he had taken all the steps in the selective process and had been finally accepted by the armed services. The question ... is whether there may be judicial review of his classification in a prosecution under $\S 11$ where he reported for induction, was finally accepted, but refused to submit to induction. ${ }^{45}$

After two long years of misconception of the Falbo case by the trial courts, during which time thousands of young men were sent to jail because they were precluded from presenting any defense-even the defense of due process-the Supreme Court disapproved of such exclusion of defense. In stating the issue, the Court said:

At the trial he sought to attack the classification given him by his local board, claiming, among other things, that it acted without any foundation of fact, discriminated against him because he was a Jehovah's Witness, and denied him the right to make full proof of his claim that he was a minister of religion. The court ruled that no such defense could be tendered. ${ }^{45}$

The Court, reviewing the Act, found that Section 11 (of the old Act which has its parallel in the Act of 1948) conferred jurisdiction on the district courts to try

2320 U.S. at 553-54. (Emphasis added.)

${ }^{43}$ Estep v. United States, 327 U.S. 114 (1946).

"I Ibid.

45 Ibid., at 115-16.

16 Ibid., at 118 . 
persons charged with offenses under the Act. As to the matter of defenses, the court said:

Sec. 11, being silent on the matter, leaves the question of available defenses in doubt. But we are loath to resolve those doubts against the accused. We cannot readily infer that Congress departed so far from the traditional concepts of a fair trial when it made the actions of the local boards "final" as to provide that a citizen of this country should go to jail for not obeying an unlawful order of an administrative agency. We are loath to believe that Congress reduced criminal trials under the Act to proceedings so barren of the customary safeguards which the law has designed for the protection of the accused. The provision making the decisions of the local boards "final" means to us that Congress chose not to give administrative action under this Act the customary scope of judicial review which obtains under other statutes. It means that the courts are not to weigh the evidence to determine whether the classification made by the local boards was justified. The decisions of the local boards made in conformity with the regulations are final even though they may be erroneous. The question of jurisdiction of the local board is reached only if there is no basis in fact for the classification which it gave the registrant. ${ }^{47}$

So it seems that at the present time, or at least since 1946, some measure of judicial review of the Draft Board's decision may be had in a criminal prosecution. The measure is a rather meager one, because the Estep case says that the decisions of the local boards made in conformity with the Regulations are final, even though they may be erroneous. The question of jurisdiction of the local board is reached only if there is no basis in fact for the classification which it gave the registrant. The Supreme Court then goes back again to the Falbo case and makes the decisions in the two cases clear by juxtaposition when it declared that the Falbo case

does not preclude such a defense in the present cases. In the Falbo case the defendant challenged the order of his local board before he had exhausted his administrative remedies. Here these registrants had pursued their administrative remedies to the end. All had been done which could be done. Submission to induction would be satisfaction of the orders of the local boards, not a further step to obtain relief from them. If $\$ 11$ were not construed to permit the accused to defend on the ground that his local board acted beyond its jurisdiction, a curious result would follow. ${ }^{48}$

Just exactly such "curious" results were obtained before the Supreme Court again spoke in the Estep case, but many of those convicted because of the misinterpretation of the $F$ albo case personally would consider the result not so much curious as tragic.

The Estep case established the right to judicial review, but in a manner which leaves the way open for every trial judge to determine for himself whether there was any basis or whether there was none for the classification given to the registrant. The case of a young conscientious objector, graduate of the University of Illinois Law School, who was recognized by his draft board as a conscientious objector because of his unquestionably deep religious beliefs, illustrates the

$$
47 \text { Ibid., at 122-23. } \quad 48 \text { Ibid., at } 123 .
$$


latitude given individual judges. This young man, after having finished his law studies, passed the Illinois Bar examination and submitted, under the Illinois rules, to questioning by members of the Committee on Character and Fitness. He admitted being an absolute believer in nonviolence, and on that sole ground was refused certification to the Supreme Court and denied a license.

A petition filed on his behalf before the Supreme Court of Illinois was denied, as was the second petition supported by letters from a great many lawyers asking that he be granted a license. After the second denial of his petition, the case was taken to the United States Supreme Court ${ }^{49}$ where, in a five to four decision (Justices Black, Douglas, Murphy and Rutledge dissenting), the right of the state of Illinois to exclude the petitioner from practicing law was upheld. The Illinois court's finding that the petitioner would be unwilling to serve in the state militia in time of war and thus would be unable to take an oath to support the Constitution of Illinois (which was interpreted to include a willingness to serve in the militia) was held not violative of any of the principles of religious freedom under the Constitution.

The subjective approach to the problems of conscientious objectors may be seen clearly by juxtaposition of Terminiello v. Chicago ${ }^{50}$ and Gara v. United States. ${ }^{51}$ In the Terminiello case, a spokesman for Gerald L.K. Smith delivered a rather harsh speech in the city of Chicago which was characterized as containing "opprobrious, abusive and insulting stories" with evidence that Terminiello "aroused his audience to feverish feelings of anger and hatred ... to a point where there were shouts to kill men and starve the Jews and send them to Russia." "52 Terminiello was found guilty of violating a city ordinance by "making an improper noise and diversion tending to a breach of peace." He was fined $\$ 200$. The conviction was upheld both by the Appellate and Supreme Courts of Illinois. The United States Supreme Court reversed the conviction on the ground that the statutory words "the breach of peace" were defined in instructions to the jury to include speech which "stirs the public to anger, invites dispute, brings a condition of unrest or creates a disturbance." The Court held that a conviction resting on any of these grounds could not stand. The petitioner himself had not excepted to the instruction which permitted conviction on the basis of "tendency."

In the Gara case, a similar instruction was given to the jury. Gara was a Quaker teacher at a Mennonite school in Ohio. He began his work at the school on September 20,1948. One of the students at the school was indicted on the ground that on September 10, 1948 (ten days before the student had even met Gara), he had failed to register for the draft. When the FBI agents came to arrest the student, they met with Gara, who was Acting Dean of Students, and he

19 In re Summers, 325 U.S. 561 (1945).

s0 337 U.S. 1 (1949).

51340 U.S. 893 (1950).

52 Chicago v. Terminiello, 400 Ill. 23, 79 N.E. 2 d 39 (1948). 
offered to take the men to the student's room. After the student had submitted to arrest, Gara said to him: "Stand by your principles. Don't let them coerce you into registering." Gara was subsequently indicted on the charge that on the day the student was arrested his "encouragement aided and abetted his student in his refusal to register." The instruction to the jury included the statement that Gara's words to the student were "of such a nature that (they) had a tendency to encourage or cause (the student) to continue his refusal to register." Gara was found guilty. His conviction was affirmed and the Supreme Court, by a four to four decision and without an opinion, upheld the lower courts.

\section{The Britrsh System}

The author's experience in Selective Service cases, which undoubtedly can be matched by all others who were called upon to defend conscientious objectors, bears out the fact that the Selective Service Acts of 1940 and 1948 and the amendment of 1951 were rashly formulated with little or no consideration of the practical application of the Rules and Regulations to be issued under the law. The results were tragic because, not only did they bring about the incarceration of a great many sincere and honest objectors to force, but they also brought into question the basic tenet of due process; that is, the right of everyone, not only the conscientious objectors themselves, but a great many others who, by disagreeing with the Rules, were ready to uphold their rights to conscience. There was no need to formulate a law as though no precedent existed, because the British National Service Act of 1939 was formulated to avoid mistakes that occurred during the first World War in the treatment of conscientious objectors.

The British Act provides for fewer boards but for highly qualified members. It permits the registration of those who claim conscientious objection on a separate register, while our law registers them together with all other prospective draftees. This latter system compelled a great many deeply religious objectors to go to jail because they felt that they could not undertake even the first step toward conscription by registering for the draft. These "absolutists," so-called, would have no objection to registration as conscientious objectors, but registering for the draft, which was considered by some of our military leaders as the "keystone of building armed forces," was beyond the step that they could conscientiously undertake.

The setting up of our appeal boards, the members of which were again selected within the framework of the political machinery of each state, presented the same problem as those encountered with local boards. The British Act provides, to the contrary, a few appeal tribunals, the members of which were highly qualified.

The penalty provisions of the Selective Service Acts of this country make it clear, beyond a peradventure of doubt, that the framers of our law believed that the conscientious objector can be deterred from his stand by confronting him with a possibility of a five-year penitentiary sentence and a $\$ 10,000$ fine. The 
British believed that a one-year sentence (subsequently raised to two years) would punish any violator of their law, while those who refused to register were presented with a "summary conviction to a fine not exceeding five pounds." In this country, hundreds of nonregistrants went to the penitentiary for three, four or five years. ${ }^{33}$

The rules providing for our appeal proceedings practically provide for "Star Chamber" proceedings, while the British National Service Act of 1939 provides that if the registrant is aggrieved by the decision of the local tribunal, he may appeal to the appellate tribunal which is empowered to take evidence and make provision for the representation of the parties to proceedings before the tribunal, including the right to appear either in person or by counsel or by friend. In addition, the Minister in charge of the enforcement of the British Act is authorized to pay not only the members of the tribunals but also applicants appearing before the tribunals and to defray expenses of necessary witnesses. This we must compare with our appeal proceedings where the registrant is not permitted to appear before the board either in person or by counsel, although he is given the opportunity to appear before the hearing officer and receive at least fragmentary information of what the "informants" had to say about his claim. While it is true that the British National Service Act of 1939 provides no appeal to the courts, their very competent local tribunal set up should be set against the local and appeal board proceedings in the United States which lack any semblance of due process, even considering the "judicial review" now permissible since the Estep decision as a concession.

\section{CONCLUSION}

Mr. John Edgar Hoover, writing in the Iowa Law Review on "Civil Liberties and Law Enforcement," said:

Democratic law enforcement is loyal to both the state and the individual. It is obligated to uphold the sovereignty of the government, yet at the very same time, to protect the rights of the citizen. ${ }^{54}$

This statement, as far as the author knows, remained unchallenged up to the present time, and it seems that students of constitutional law agree with $\mathrm{Mr}$. Hoover's statement that there is such a thing as "sovereignty of the government," forgetting entirely that the sovereignty rests with the people and not with the government.

This new concept, so introduced by Mr. Hoover and apparently accepted by constitutional students, explains the conflict with which conscientious objectors found themselves confronted during and after the wars. The conscientious objectors apparently believe that they-because they are of the people-are the sovereigns and that the state has only such rights and powers as are delegated to it by the people by the Constitution. They oppose the new concept that gives

${ }^{88}$ United States v. Kime, 188 F. $2 d 677$ (C.A. 7th, 1951), cert. denied, 342 U.S. 823 (1951).

s4 Hoover, Civil Liberties and Law Enforcement, 37 Iowa L. Rev. 149 (1952). 
the sovereignty to the government, and, of course, takes it away from the people.

The conscientious objectors appearing before the courts and demanding their unhampered right of exercising their religion freely are the ones who are directing our attention to the first concepts underlying our Constitution, concepts which, during the past one hundred fifty years, seem to have disappeared more and more. By so emphasizing the right of the individual against the power of the all-embracing state, the conscientious objectors place themselves in the forefront of those who believe that civil rights and civil laws of the individual must be protected, not alone because of the individuals involved, but because of the grave danger that disregarding the civil rights of the individuals and of minority groups will be the first step to the concept of a totalitarian state wherein the rights of all citizens are disregarded because they are to be subordinated to a new and false concept- "the sovereignty of the state." 